\title{
INEQUALITIES INVOLVING THE KHATRI-RAO PRODUCT OF MATRICES
}

\section{JADRANKA MIĆIĆ}

Abstract. We shall show several complementary inequalities to Jensen's type inequality involving the Khatri-Rao product of maps on positive definite matrices. They are applied to extend some known inequalities involving powers of the Khatri-Rao product. Finally, we have generalized some known results for the Hadamard product of operators.

Mathematics subject classification (2000): 15A45, 15A69.

Keywords and phrases: Matrix inequality, Khatri-Rao product, Tracy-Singh product, Hadamard product, Kronecker product, Mond-Pečarić method.

\section{REFERENCES}

[1] J. S. Aujla AND H. L. VAsudeva, Inequalities involving Hadamard product and operator means, Math. Japon. 42 (1995), 265-272.

[2] C. CAO, X. Zhang AND Z. YAng, Some inequalities for the Khatri-Rao product of matrices, Elect. J. Linear Alg., 9 (2002), 276-281.

[3] J. I. FuJII, The Marcus-Khan theorem for Hilbert space operators, Math. Japon., 41 (1995), 531-535.

[4] T. FurutA, J. Mićić Hot, J. PeČARIĆ AND Y. SEO, Mond-Pečarić method in operator inequalities, Element, Zagreb, 2005.

[5] R. H. Koning, H. Neudecker and T. WAnsbeek, Block Kronecker products and the vecb operator, Linear Algebra Appl., 149 (1991), 165-184.

[6] S. LiU, Matrix results on the Khatri-Rao and Tracy-Singh products, Linear Alg. Appl., 289 (1999), 267-277.

[7] S. LiU, Some inequalities involving Khatri-Rao product of positive semi-definite matrices, Linear Alg. Appl., 354 (2002), 175-186.

[8] J. MiĆIĆ AND J. PEČARIĆ, Order among power means of positive operators, II, submitted to Sci. Math. Japon.

[9] J. MiĆIĆ, J. PEČARIĆ AND Y. SEO, Function order of positive operators based on the Mond-Pečarić method, Linear Alg. Appl., 360 (2003), 15-34.

[10] J. Mićić, J. E. PeČarić, Y. Seo and M. Tominaga, Inequalities for positive linear maps on Hermitian matrices, Math. Inequal. Appl., 3 (2000), 559-591.

[11] J. PeČARIĆ AND J. MićIĆ, Some function reversing the order of positive operators, Linear Alg. Appl., 396 (2005), 175-187.

[12] Z. A. Al Zhour AND A. Kilicman, Extension and generalization inequalities involving the KhatriRao product of several positive matrices, J. Inequal. Appl., 2006 (2006), 1-21. 